\title{
MORAL VALUES IN NARRATIVE TEXTS OF ENGLISH TEXTBOOKS FOR SENIOR HIGH SCHOOL STUDENTS PUBLISHED BY THE MINISTRY OF EDUCATION AND CULTURE
}

\author{
Iwan Setiawan, Fahriany \\ Syarif Hidayatullah State Islamic University of Jakarta, Indonesia \\ (fahriany@uinjkt.ac.id.ac.id)
}

Received: $4{ }^{\text {th }}$ October 2017; Revised: $28^{\text {th }}$ November 2017; Accepted: $28^{\text {th }}$ December 2017

\section{ABSTRACT}

This study aimed to reveal the moral values in the narrative texts of English textbooks for senior high school students published by the Ministry of Education and Culture and also the English teachers' and students' responses at SMK Triguna Utama, South Tangerang City, related to the topic under investigation. This research used content analysis design. The data sources were the narrative texts in the English textbooks and teachers' and students' responses. The data were collected through documentation, interview, and questionnaire. Data analysis procedures consisted of perusing, eliciting, coding, tabulating, interpreting, drawing conclusions and validating. The research found that the English textbooks lacked fables and gave a smaller portion to Indonesian local stories. Moreover, the narrative texts were dominated by the value of kindness, while, fairness was included least explicitly in the stories. These findings were supported by the views and preferences of the teachers and students. Lastly, the teachers and students compactly argued that vocabulary is the greatest barrier to teaching and learning narrative text, and the effectiveness of the school's atmosphere in instilling moral values still needed further research.

Key Words: english textbooks; narrative texts; moral values; content analysis

\section{ABSTRAK}

Penelitian ini bertujuan untuk mengungkap nilai-nilai moral dalam teks naratif buku teks bahasa Inggris untuk siswa Sekolah Menengah Atas yang diterbitkan oleh Kementerian Pendidikan dan Kebudayaan dan juga tanggapan guru dan siswa bahasa Inggris di SMK Triguna Utama, Kota Tangerang Selatan, terkait dengan topik yang diselidiki. Penelitian ini menggunakan desain analisis isi. Sumber datanya adalah teks naratif dalam buku teks bahasa Inggris dan tanggapan guru dan siswa. Data dikumpulkan melalui dokumentasi, wawancara dan angket. Sedangkan, prosedur analisis data meliputi pembacaan teks secara cermat, pemilahan data, penyandian, tabulasi, interpretasi, penarikan simpulan dan validasi. Penelitian ini menemukan bahwa buku teks bahasa Inggris tersebut masih kekurangan fabel dan cerita lokal Indonesia. Selain itu, teks naratif didominasi oleh nilai kebaikan, sementara nilai keadilan kurang tergambarkan dalam cerita. Temuan ini didukung oleh pandangan dan preferensi para guru dan siswa. Terakhir, para guru dan siswa secara sepakat berpendapat bahwa kosa kata merupakan penghalang terbesar dalam pengajaran dan pembelajaran teks naratif, dan efektivitas atmosfer sekolah dalam menanamkan nilai moral masih memerlukan penelitian lebih lanjut.

Kata Kunci: buku teks bahasa inggris, teks naratif, nilai moral, analisis isi

How to Cite: Setiawan, I., Fahriany. (2017). Moral Values in Narrative Texts of English Textbooks for Senior High School Students Published by the Ministry of Education and Culture. IJEE (Indonesian Journal of English Education), 4(2), 130-143. doi:10.15408/ijee.v4i2.5977 


\section{INTRODUCTION}

Textbooks play a prominent role in teaching and learning activities including in TEFL (Teaching English as a Foreign Language) context. The school textbooks may serve a variety of functions and meet a range of objectives. They are not simply the everyday tools of the language teacher, but also the embodiment of the aims, values, and methods of the particular teaching-learning situation (Wong, 2011). Textbooks as teaching materials consist of innumerable things such as reading passages, dialogues, grammatical rules, activities, exercises, practices, essays, photos, tables, charts, et cetera-definitely the texts as well.

However, textbooks often contain ideologically-oriented values, cultural biases, and social stereotypes. As Richards (2001) asserted that they may distort content. Many studies have demonstrated that racist attitudes, linguistics biases, gender dominance and cultural prejudices constitute part of the unrealistic view of the textbooks (Ansary \& Babaii, 2003). Some authors criticized the textbooks for providing an unnatural and inauthentic language which fails to contribute to communicative practice. For an instance, Richards (2010) pointed out the advantages of textbooks as follows: a) they provide a structure and/or a syllabus for a program; b) They help standardize instruction; c) they provide a variety of learning resources; d)they can provide effective language models and inputs; e) they can train teachers and help saving time; and f) they are visually appealing.

On the other hand, they have unfortunately some disadvantages as well such as: a) they may contain inauthentic language; b) they may distort content; c) they may not reflect students' needs; d) they can deskill teachers; and e) they are expensive.

Moreover, texts as pieces of spoken or written language are created for a particular purpose. The purpose might be to persuade, to inform or a combination of both. The context in which the text is spoken or written is likewise influenced by our culture (beliefs, attitudes, values) and situation (what is happening, who is involved and whether we are speaking or writing).

A narrative text is one sort of the literary texts. The purpose of a narrative text is, other than providing entertainment, can be to make the audience think about an issue, teach them a lesson, or excite their emotions (Anderson \& Anderson, 2003). So, among its purposes, a narrative text can convey and instill moral values/lessons/messages to their 
readers (Anderson \& Anderson, 2003; Rosenstand, 2006; Buscemi, 2002; Pharr \& Buscemi, 2005; Benyamin, 2012).

In line with that, character building or often called as character education is one of the main spirits of our national education. It is stated that, "education is a conscious and planned effort to enhance teaching-learning activities so that the students can actively develop their potentials to acquire religiousspiritual qualities, self-control, personality, knowledge, good characters, and all they need as parts of the society, nation, and country (Constitutions of Republic of Indonesia No. 20 about National Education System, 2003)." Likewise, Halstead (2007) stated that teaching morality in the light of Islam is a moral duty itself. Morality (or ethics) is thus the main core of Islamic teachings as well.

In fact, our national educational system has not reached its optimum goals including the character building of the learners particularly and of the society in general. Ironically, we can see clearly now our country is still facing unrelieved moral degradation of all levels of the nation - to mention a few: chronic corruption, collusion, nepotism, horizontal conflicts, religious intolerance, student brawls, illicit drug uses, free sex, sexual abuses and still many others. Undoubtedly, there are various factors that influence the development of our moral values including parents, religious beliefs and involvement, peers, media, and many others (Marsh, 2010).

The implantation of moral values in our education is, therefore, a crucial issue. Moral education can be inculcated implicitly and/or explicitly within the curriculum used in the schools. In the classroom, teachers may choose to nurture these values through the processes of perspective taking, storytelling, cultural transmission, moral dilemmas, responsible decisionmaking, service learning and community involvement (Cubukcu, 2014). Once more, it is an urgent need and top priority to conduct a research on (moral) value-based education to tackle all these deteriorating moral crises of our students/pupils and to enhance the quality of our national education and achieve its optimum goals. One of the real efforts is through content analysis of the textbooks, i.e. narrative texts, in particular, inculcated with the moral values.

Furthermore, there are a plethora of types and definitions of values ubiquitously. According to Wibowo (2001), for instance, there are at least four known values that generally established and acted upon in our 
society, i.e., moral, social, constitutional (legal), and religious values.

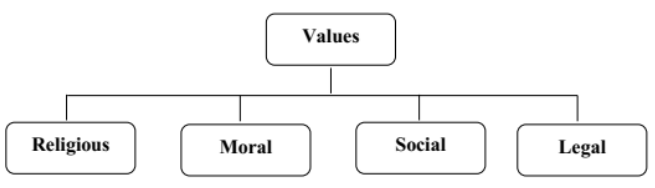

Figure 1. Four Types of Values (Wibowo, 2001)

Moral values were defined as having an interpersonal focus, which, when violated, arouse pangs of guilt for wrong-doing (Abdolmohammadi \& Baker, 2006). Moral values are not separated from other values. Each value can obtain a" moral weight" when included in moral behavior. Honesty, for an instance, is a moral value, but honesty itself is empty if it is not applied to other values, such as the economic value. Loyalty is also a moral value but must be applied to the more general human values, for example, love between husband and wife. Thus, the values of the heretofore are" premoral." Values precede moral stages but could receive" moral weight," as they were applied in moral behavior. Although moral values usually enjoin other values, it appears as a new value, even as the highest value (Bertens, 2011).

However, there are some features which distinguish moral values to other values. According to Bertens (2011), there are at least four main characteristics: a) responsible, related to human as responsible people which make them feel guilty or not in deciding a moral action in a particular moral problem or dilemma - not so as are other values; b) consciouslymotivated/intended, moral values are a kind of appeal from our conscience that seriously and urgently to admit, communicate and realize promptly; c) obligatory, values oblige us to admit and act upon them absolutely and unconditionally; otherwise, we would be feeling guilty and/or reprehensible; and, d) formal, means related or connected to other values inherently.

Furthermore, Sudarminta (2015) elaborated in more detail some prerequisites of what we call as moral values. Moral values should be: a) rational and emotive, based on rational and emotional considerations as a complete human being equipped with cognitive and affective competencies in contrary to emotivism; b) consistently logical and flexible, comprised of logical consistency and flexibility simultaneously so there are still possibly any exceptions in some certain (moral) cases; c) universal as well as particular, as an adequate moral (values) theory, these two aspects should be included as well, this is in line with the second traits above; and d) solutive, can provide a moral solution in a dilemmatic moral problem or case. 
Afterwards, considering the numerous theories and concepts related to moral values and due to the plethora of moral values identified and some values that were universally accepted throughout the previous studies (such as justice, respect, responsibility, and so forth), this study focused on five basically key moral values, i.e., kindness, honesty, respect, responsibility, and fairness. Moreover, their definitions and synonyms as a checklist have also been devised and applied during the analytical process. The writers argued that five prominent values are most important and relevant to be instilled particularly to the students at the secondary schools through narrative texts in the English textbooks based on the theoretical and empirical considerations.

Thus, this research focused on those moral values incorporated in narrative texts of the English textbooks for senior high school students published by the Ministry of Education and Culture in the form of a content analysis study. Relating to that focus, some main research objectives could then be derived, i.e. to describe how narrative texts inculcated with moral values presented in the English textbooks for senior high school students published by the Ministry of Education and Culture; to analyze \& identify the moral values which were frequently incorporated in them; and also to reveal the teachers' and students' responses and perspectives regarding the issue under study.

\section{METHODS}

This research used a content analysis method. Krippendorf (2004) defined it as a research technique for making replicable and valid inferences from texts (or other meaningful matter) to the contexts of their use. Furthermore, Neuendorf (2002) explained that content analysis may be briefly defined as the systematic, objective, quantitative analysis of message characters. It could be used to analyze various types of communication, e.g., newspaper, radio news, TV advertisements, books, and many other documents. Besides, since this research was presented in qualitative and descriptive approach, it was emergent (several aspects may emerge during the study), fundamentally interpretive, took place in the natural setting, used multiple methods and strategies of inquiry, used complex reasoning, viewed social phenomena holistically, et cetera (Creswell, 2003).

The setting of the research consisted of place, time, and condition. The data collection was conducted at SMK Triguna Utama (Triguna Utama 
Vocational High School) located on $\mathrm{Km}$. 2 Ir. H. Juanda Street, East Ciputat district, South Tangerang City, Banten Province. The research was organized in grade $X$ and $X I$ (Accounting vocational program) of the school.

In addition, the primary research resource was definitely the narrative texts of four English textbooks for senior high school students published by the Ministry of Education and Culture, i.e., Bahasa Inggris untuk $S M A / M A / S M K / M A K$. Afterward, the criteria of the participants whom the researchers involved in the research were those who took part in using those English textbooks and taught and/or learned the narrative texts inculcated with moral values, i.e., the English teachers and students from grade $X$ to XI of SMK Triguna Utama. The researchers selected 15 students (as samples) from each class (30 students in total) to answer the questionnaire sheets and 2 English teachers from both grades to be interviewed.

Moreover, the key instrument was the researchers since they possessed background knowledge and theoretical framework of the research. Besides, the other instruments used were interview and questionnaire questions to explore and investigate the teachers' and students' responses regarding the issue under investigation.
Lastly, the data analysis procedures in this study involved the following steps, i.e., perusing, eliciting, tabulating, coding, interpreting, drawing conclusions, and validating (adapted from Krippendorf, 2004).

\section{FINDINGS AND DISCUSSION}

\section{Presentation of Narrative Texts inculcated with Moral Values}

The narrative texts of the English textbook series published by the government were presented in four text types. In total, eight narrative texts were found in the textbooks presented in those four types of narrative texts.

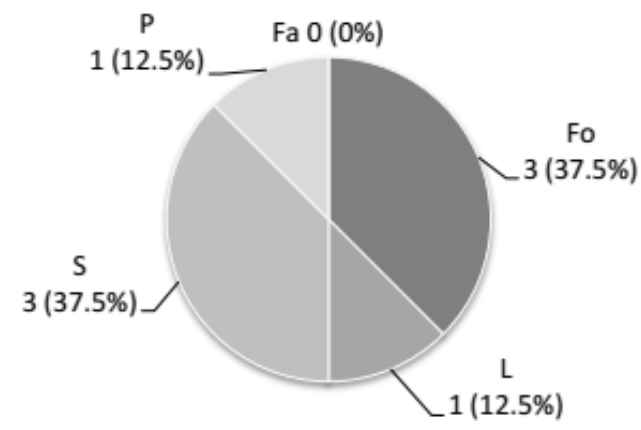

Chart 1. Total Frequency of Narrative Text

Types in Bahasa Inggris untuk

SMA/MA/SMK/MAK Kelas X and XI

Firstly, they were three narrative texts in the form of folklores/folktalles, i.e., "Issumboshi," a Japanese folktale/fairytale (Furaidah et al., 2014b, pp. 49-51); "Strong Wind," a folktale of a native American tribe 
(Furaidah et al., 2014b, pp. 89-91); and "The Enchanted Fish," a classic folklore/tale written by Grimm brothers, i.e., Jacob and Wilhelm Grimm, in 1812 (Bashir, 2014a, pp. 3 5).

Secondly, there was only one legend found in the English textbook series, that was, in Bahasa Inggris untuk SMA/MA/SMK/MAK Kelas X Semester 2. The story was about "Malin Kundang", a well-known Indonesian legend from Padang, West Sumatra (Furaidah et al., 2014b, p. 64).

Furthermore, there was a narrative in the form of a play in the English textbook, namely Bahasa Inggris untuk SMA/MA/SMK/MAK Kelas X Semester 2, though this type of text was excluded from the analysis due to validating process as this research focus on the text in a real sense - i.e., the play presented in the form of dialogue. The play was entitled Vanity and Pride (Bashir, 2004a, pp. 70-74).

The last, three narratives were presented in the form of short stories. They were "Congratulation!" in chapter four of Bahasa Inggris untuk SMA/MA/SMK/MAK Kelas X Semester 1 (Furaidah et al., 2014a, pp. 45-46); "Letter to God," a short story written by a Mexican writer, Gregorio López y Fuentes (Bashir, 2014a, pp. 92-95); and "The Last Leaf" is a short story written by $\mathrm{O}$. Henry, an American short story writer (Bashir, 2014b, pp. 47-49).

Regarding those types of narrative texts occurred in the textbook series, from my point of view, it shows a balanced proportion of types of narrative texts appeared which emphasized on the folklore and short story genres since both types are commonly written and/or read by the readers when they look for fictive texts as (reading) learning materials and/or for fun only. Nonetheless, fables which are also good and fun materials for young learners were not found at all (Abrar, 2016; Verner, 2016). Besides, Indonesian stories (e.g. its folklores or fables) should be given more proportion since the current trend in TEFL (Teaching English as a Foreign Language) that further emphasized using the local stories as the media to learn the target language. By presenting the authentic and meaningful materials, the students therefore while learning the foreign language could also effectively express their identities and culture in the target language (Torun \& Yildirim, 2014; Kilickaya, 2004).

\section{Moral Values in Narrative Texts}

Subsequently, having discussed the presentation of the types of narrative texts, this study also tried to elaborate the moral values in those narrative 
texts. In this analysis, five main moral values were analyzed to categorize all moral values which came up in the narrative texts, i.e., kindness, respect, responsibility, honesty, and fairness, and attempted to be uncovered from the stories in the English textbook series.

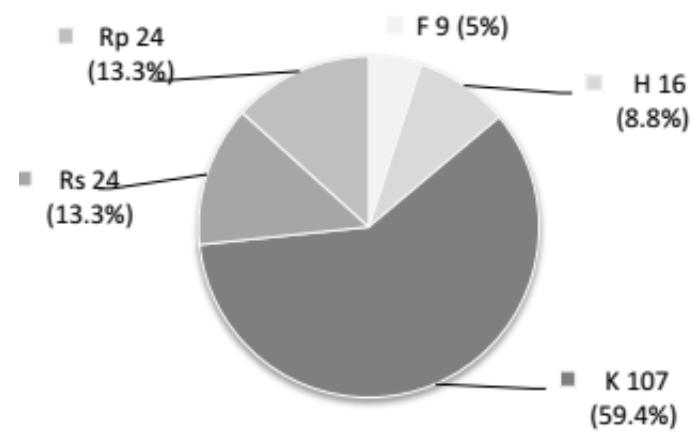

Chart 2. Total Frequency of Moral Values inculcated in Narrative Texts of Bahasa Inggris untuk SMA/MA/SMK/MAK Kelas X and $X I$

As indicated by the data in Chart 2 above, the moral value, kindness, make up the highest frequency by 59.4\% (107 times) spread in seven different stories. While, three other moral values, i.e., honesty with $8.8 \%$ or 16 times, respect and responsibility share similar proportions by $13.3 \%$ or 24 times for each. They were instilled implicitly or explicitly in all seven narratives of the English textbook series under study. Unfortunately, another important moral value, namely fairness, was implied only once at least implicitly by only nine times or $5.8 \%$. Though, this value is indeed an important value as well to be learned and exemplified by the students through reading narrative texts implied with it. Moreover, in terms of citizenship, this value is a crucial one since the society that lacks it would not succeed (Tay \& Yildirim, 2009; Rachels, 2003; Welsh, 2014). In conclusion, all these key moral values and narrative texts which present them should be taken into account considerately by the textbook writers, users, teachers, and students, and, at best, be provided with a balanced proportion as well.

\section{English Teachers' and Students' Responses regarding Moral Values in Narrative Texts}

The English teachers' and students' responses describing their views, perceptions and/or perspectives about the issue were attempted to be analyzed and elaborated as well in this section. According to Mrs. DN, the English teacher of grade $X$, she usually found the moral values of honesty, autonomy/self-sufficient, courage, and hard work. While, Mr. NW, the English teacher of grade XI, said that he mostly found the values such as gratitude, respect, honesty, optimism, sacrifice for other's goodness, and so forth. Moreover, conversing on the selected 
key moral values that were applied and discussed throughout this study, they thought that those are vital in educating and instilling into their students as by acquiring those morals the students can be good people and they can live well and harmoniously in the society.

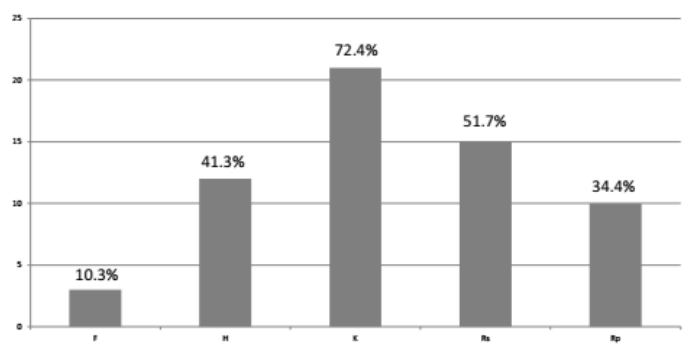

Chart 3. Students' Preferences on the Key Moral Values

On the other hand, the questionnaires were also distributed to gather students' preferences of the key moral values that should be placed more importance among others. Though in terms of values lexically, they did not express them explicitly, the researchers have attempted to look for their meanings and synonyms that matched most those key values based on the devised checklist. The results of the respondents' answers in order are as follows: kindness, as much as $72 \%$ (21 respondents); respect, 52\% (15 respondents); honesty, $41 \%$ respondents); responsibility, $34 \%$ (10 respondents); and fairness, $10 \%$ (3 respondents only). Respectively, these results are slightly similar to those of the previous finding discussing the key moral values found in the textbooks, specifically in the narrative texts. The two moral values apparently dominated the highest and lowest frequencies of the moral values appeared and preferred; they were kindness as the highest frequency and fairness as the lowest one.

Regarding their methods in teaching narrative texts, Mrs. DN, explained that she preferred to use (audio-visual) media in teaching narrative texts (surely instilled with morals). On the other hand, slightly different from the first view shown by the second English teacher in grade XI, he thought that discussion and question and answer were preferred best.

Generally, like other teachinglearning activities, there are some barriers or obstacles in succeeding to inculcate those values to the students as experienced by the interviewed English teachers. Vocabulary still seemed to be the greatest barrier as admonished by both English teachers and students in teaching and learning narrative texts, and, therefore, the students felt difficult to understand the texts and to infer the moral values from them and applying them in daily lives.

Henceforth, the atmosphere of the school is also one of the influencing factors in instilling the good characters into their students. The good 
atmosphere can indeed affect the success of instilling moral values and therefore create good students. Conversely, the bad atmosphere cannot surely guarantee the character building of the students, but, can influence bad characters to them, and the learning objectives could not be achieved. Nonetheless, good testimonies were shown by the English teachers and some students related to the atmosphere of the school in cultivating the values, there were still many factors/aspects to be investigated to assure the success of the cultivation of moral values for their students (see Lickona et al., 2007).

\section{CONCLUSION AND SUGGESTION}

Based on the findings and discussion of the research, several conclusions could be made as follows.

Firstly, among the various types of narratives presented in the English textbooks (i.e., folklores/folktales, a legend, a play, and short stories), fables and Indonesian local stories have unfortunately the least places in the textbook series regarding their ability and authenticity to draw the readers' interest and motivation.

Secondly, it was found most significantly the value of kindness in the textbook series and followed in order by three other moral values, i.e., respect, responsibility, and honesty. However, the value of fairness is included at the very least explicitly in the stories provided in the English textbooks.

Subsequently, the lack of the value of fairness is also evident in the perceptions and preferences of the English teachers and their students.

Fourth, in terms of narrative text teaching and learning process, the teachers and students in unison agreed that vocabulary is the most unrelieved barrier they encounter.

The last, despite the availability and completeness of facilities and morally induced activities at SMK Triguna Utama, it could not guarantee efficiency nor effectiveness of the moral education at the school. Serious and indepth efforts have to be taken to assure the effectiveness of the cultivation of moral values.

Based on the aforementioned conclusions, some suggestions and recommendations could be offered to expectedly enhance the quality of contents of the English textbooks and to ascertain the success of the values inculcation to the students.

The English textbook authors should provide a more proportional portion of narrative texts, particularly 
the stories from Indonesian rich local culture which could be meaningful and authentic teaching materials for the learners, and the inclusion of the fables should also be taken into account so the textbooks would be richer, more fun and attract students' interest.

Next, since the English textbooks under study were lacking in terms of the moral value of fairness, it thus should be a top priority to place more emphasis and inclusion of the stories about fairness or justice. This value is certainly needed in the context of our national and global lives.

Thirdly, noticing the biggest problem faced by the learners is vocabulary, therefore, students activities and assignments to improve their vocabulary is inevitable. For instance, by encouraging and instructing the students to read English novels, short stories, or other genres of texts inside or outside the classroom, and to use current technology optimally in teaching learning process so they would be more assisted, easier, and surely more fun.

Lastly, it is also suggested that a careful content analysis regarding the in-use textbooks should be conducted by the school authorities and/or teachers to determine the strengths and the weaknesses of the textbooks, and therefore make initiative actions to alleviate those weaknesses to achieve maximum instructional objectives and to enhance moral education in the EFL context at last.

\section{REFERENCES}

Abdolmohammadi, M. J., \& Baker, C. R. (2006). Accountants' Value Preferences and Moral Reasoning. Journal of Business Ethics, 69, pp. 11-25. Retrieved from http://ethicaldevelopment.ua.edu/u ploads/8/4/9/8/84986096/_2006_a ccountants_value_preferences_and_ moral_reasoning.pdf.

Abrar, M. (2016). Learning from Fables: Moral Values in Three Selected English Stories. Dinamika Ilmu, 16 (1), pp. $47-58$.

Anderson, M., \& Anderson, K. (2003). Text Types in English 3. South Yarra, VIC: MacMillan Education Australia.

Ansary, H., \& Babaii, E. (2003). Subliminal Sexism in Current ESL/EFL Textbooks. Asian-EFL Journal, 5 (1). Retrieved from http://www.asianefljournal.com/march03.sub1.htm

Ashiba, S. A. A. (2010). An Analysis of the Incorporated Values in English for Palestine 12 (A Master's Thesis at Curriculum \& English Teaching Methods Department of Faculty of Education, Islamic University of Gaza), Retrieved from http://library.iugaza.edu.ps/thesis/ 92226.pdf.

Aytan, T, Başal, A., \& Demir, I. (2016). Teaching Vocabulary with Graphic Novels. English Language Teaching, 9 (9), pp. 95-109. Retrieved from 
http://dx.doi.org/10.5539/elt.v9n9p 95.

Bashir, M. (2014a). Bahasa Inggris untuk SMA/MA/SMK/MAK Kelas XI Semester 1. Jakarta: Kementerian Pendidikan dan Kebudayaan.

Benyamin, H. (2012). Advanced Learning English 1. Bandung: Grafindo Media Pratama.

Bertens, K. (2011). Etika (11 th ed.). Jakarta: Gramedia Pustaka Utama.

Bonk, C. J. (2009). The World is Open: How Web Technology is Revolutionizing Education. San Francisco, CA: JosseyBass.

Bross, J. A. (2004). Ethics for Life (3 $3^{\text {rd }}$ ed.). New York, NY: McGraw Hill.

Buscemi, S. V. (2002). A Reader for Developing Writers ( $5^{\text {th }} \mathrm{ed}$.). New York, NY: McGraw-Hill Companies, Inc.

Clouse, B. F. (2008). The Student Writer: Editor \& Critic ( $7^{\text {th }}$ ed.) New York, NY: McGraw-Hill Companies, Inc.

Creswell, J. W. (2003). Research Design: Qualitative, Quantitative, and Mixed Method Approaches ( ${ }^{\text {nd }}$ ed.). Thousand Oaks, CA: Sage Publications.

Cubukcu, F. (2014). Values Education through Literature in English Classes. Procedia - Social and Behavioral Sciences, 116 , pp. 265-269. Retrieved from

http://doi:10.1016/j.sbspro.2014.01.2 06.

Denzin, N. K. (2009). The Research Act: A Theoretical Introduction to Sociological Methods. New York. McGraw Hill.

Departemen Pendidikan Nasional. (2006). Undang-Undang Republik Indonesia No. 20 Tahun 2003 Tentang Sistem
Pendidikan Nasional. Jakarta: Departemen Pendidikan Nasional.

Furaidah, Rohmah, Z., \& Widiati, U. (2014a). Bahasa Inggris untuk SMA/MA/SMK/MAK Kelas X Semester 1. Jakarta: Kementerian Pendidikan dan Kebudayaan.

Halstead, J. M. (2007). Islamic Values: A Distinctive Framework for Moral Education. Journal of Moral Education, 36 (3), pp. 283-296. doi: $10.1080 / 03057240701643056$.

Hasan, S. S. (2011). Pengantar Cultural Studies: Sejarah, Pendekatan Konseptual, dan Isu Menuju Studi Kebudayaan Kapitalisme Lanjutan. Yogyakarta: Ar-Ruz Media.

Herlina (2012). Developing Reading Narrative Text Materials for Eighth Graders of Junior High School Implemented with Character Building. English Education Journal, 2 (2), pp. 147-154. Retrieved from http://journal.unnes.ac.id/sju/index .php/eej.

Karatay, H. (2011). Transfer of Values in the Turkish and Western Children's Literary Works: Character Education in Turkey. Educ. Res. Rev, 6 (6), pp. 72-480. Retrieved from http://www.academicjournals.org/a rticle/article1379691398_Karatay.pdf.

Kasim, M. (2014). Konsep dan Implementasi Kurikulum 2013. Jakarta: Kementerian Pendidikan dan Kebudayaan.

Kemdikbud. (2010). The Role of Textbooks in a Language Program. Retrieved from

http://www.professorjackrichards.c om/pdfs/role-of-textbooks.pdf.

Kemdikbud. (2014b). Bahasa Inggris untuk SMA/MA/SMK/MAK Kelas X Semester 
2. Jakarta: Kementerian Pendidikan dan Kebudayaan.

Kemdikbud. (2014b). Bahasa Inggris untuk SMA/MA/SMK/MAK Kelas XI Semester 2. Jakarta: Kementerian Pendidikan dan Kebudayaan.

Kemdikbud. (2015). Bahasa Inggris untuk SMA/MA/SMK/MAK Kelas XII. Jakarta: Kementerian Pendidikan dan Kebudayaan.

Kemdikbud. (2016). Silabus Mata Pelajaran Bahasa Inggris SMA/MA/SMK/MAK. Jakarta: Kemdikbud.

Kiliç, A. (2012). The Relationship of Values in Elementary School $4^{\text {th }}$ Grade Social Studies Textbook with the Attainments and Their Level of Being Included in Student Workbooks. Educational Consultancy and Research Center, 12 (2), pp. 1605-1612. Retrieved from http:/ / files.eric.ed.gov/fulltext/EJ98 7863.pdf.

Kilickaya, F. (2002) Authentic Materials and Cultural Content in EFL Classrroms. The Internet TESL Journal, 8 (5), pp. 67-73. Retrieved from http://iteslj.org/Techniques/Kilicka ya-AutenticMaterial.html.

Kipfer, B. A. (2009). Roget's 21 ${ }^{\text {st }}$ Century Thesaurus (3 ${ }^{\text {rd }}$ ed.). New York, NY: Dell Pub.

Krippendorff, K. (2004). Content Analysis: An Introduction to Its Methodology (2 ${ }^{\text {nd }}$ ed.). Thousand Oaks, CA: Sage Publications.

Lickona, T., Schaps, E., \& Lewis, C. (2007). CEP's Eleven Principles of Effective Character Education. Washington, DC: Character Education Partnership.
Lovat, T., Dally, K., Clement, N., \& Toomey, R. (2011). Values Pedagogy and Student Achievement: Contemporary Research Evidence. New York, NY: Springer.

Magnis-Suseno, F. (2005). Etika Dasar: Masalah-Masalah Pokok Filsafat Moral (17th $e d$.). Yogyakarta: Kanisius.

Marsh, C. (2010). Becoming A Teacher: Knowledge, Skills and Issues (5 $5^{\text {th }}$ ed.). New South Wales: Pearson Australia.

Meuleman, J. (2005). Islam in the Era of Globalization: Muslim Attitudes towards Modernity and Identity. Oxfordshire: Taylor \& Francis Group.

Michael, S. (2000). Lived effects of the Contemporary Economy: Globalization, Inequality, and Consumer Society. Public Culture, 12 (2), pp. 375-409. Retrieved from http://www.lse.ac.uk/geographyAn dEnvironment/whosWho/profiles/ Michael\%20Storper/pdf/LivedEffect s.pdf.

Narvaez, D. (2002). Does Reading Moral Stories Build Character? Educational Psychology Review, 14 (2), pp. 155171.

Neuendorf, K. A. (2002). The Content Analysis Guidebook. Thousand Oaks, CA: Sage Publications.

Ocal, A., Kyburiene, L., \& Yigittir, S. (2012). A Comparative Study on Value Tendency of University Students: $A n$ International Perspective. Citizenship, Social and Economic Education, 11 (1), pp. 11-20. Retrieved from http://www.wwwords.co.uk/CSEE.

Pharr, D., \& Buscemi, S. V. (2005). Writing Today: Contexts $\mathcal{E}$ Options for the Real World. New York, NY: McGraw-Hill Companies, Inc. 
Rachels, J. (2003). The Elements of Moral Philosophy ( $4^{\text {th }}$ ed.). New York, NY: McGraw Hill Company.

Ratna, N. K. (2014). Peranan Karya Sastra, Seni, dan Budaya dalam Pendidikan Karakter. Yogyakarta: Pustaka Pelajar.

Richards, J. C. (2001a). Curriculum Development in Language Teaching. New York: Cambridge University Press.

Rosenstand, N. (2006). The Moral of the Story (5 $5^{\text {th }}$ ed.). New York, NY: McGrawHill Companies, Inc.

Sallabas, M. E. (2013). Analysis of Narrative Texts in Secondary School Textbooks in Terms of Values Education. African Journal of Business Education, 1 (3), pp. $58-63$.

Siahaan, S., \& Shinoda, K. (2008). Generic Text Structure. Yogyakarta: Graha Ilmu.

Stanford, J. A., (2006). Responding to Literature (5 $5^{\text {th }}$ ed.). New York, NY: McGraw Hill Company, Inc.

Sudarminta, J. (2015). Etika Umum: Kajian Tentang Beberapa Masalah Pokok dan Teori Etika Normatif (3rd ed.). Yogyakarta: Kanisius.

Tay, B., \& Yıldırım, K. (2009). Parents' Views Regarding the Values Aimed to be Taught in Social Studies Lessons. Educational Sciences: Theory $\mathcal{E}$ Practice, 9 (3), pp. 1529-1542. Retrieved from http:/ / files.eric.ed.gov/fulltext/EJ85 8931.pdf.
Torun, F. P., \& Yildırım, R. (2014). Exploring the Value of Animated Stories with Young English Langugae Learners. The Turkish Online Journal of Educational Technology, 13 (4), pp. 47-60. Retrieved from http://www.tojet.net/articles/v13i4 /1346.pdf.

Verner, S. (2016). Fable Time: Using and Writing Fables in the ESL Classroom. Retrieved from http:/ / busyteacher.org/8643-usingwriting-fables-esl-classroom.html.

Welsh, A. (2014). Promoting Respect for Difference through Language Teaching. TEFLIN, 25 (2), pp. 233242.

Wibowo, M. E. (2001). Etika dan Moral dalam Pembelajaran. Jakarta: PAU-PPAI Universitas Terbuka.

Wong, P. W. L. (2011). Textbook Evaluation: A Framework for Evaluating the Fitness of the Hong Kong New Secondary School (NSS) Curriculum. (A Dissertation at Department of English, City University of Hong Kong). 